\title{
Ground water flow modeling for calibrating steady state using MODFLOW software: a case study of Mahesh River basin, India
}

\author{
S. F. R. Khadri ${ }^{1} \cdot$ Chaitanya Pande $^{1}$
}

Received: 4 November 2015/Accepted: 7 November 2015/Published online: 29 February 2016

(C) Springer International Publishing Switzerland 2016

\begin{abstract}
MODFLOW is a groundwater modelling program. It can be compiled and remedied according to the practical applications. Because structure and fixed data format, MODFLOW can be integrated with geographic information system (GIS) for ground water resource management. Groundwater is a distinguished component of the hydrologic cycle. Groundwater is the water which occupies the voids in the saturated zone of earth's crust (rocks). It moves and stores in pore space (voids) of sedimentary rocks or in the fractures and joints of hard rocks. The uncertainty about the occurrence, distribution and quality aspect of groundwater and the energy requirement for its withdrawal impose restriction on exploitation of groundwater. In spite of its uncertainty, groundwater is much protected from pollution; it requires little treatment before it use; it is available almost everywhere; it can be developed with little gestation period and can be supplied at a fairly steady rate. A groundwater model is thus a simplified version of the real system that approximately simulates the input-output stresses and response relations of the system. One has to understand here that normally the real system is simplified to model the system as such there is no unique model for a given groundwater system. Groundwater flow models are used to calculate the rate and direction of movement of groundwater through aquifers. The outputs from model simulation are the hydraulic heads and groundwater flow rates which are in equilibrium with the specified hydrogeological conditions (i.e. hydrogeological framework, hydrologic boundaries, initial and transient conditions,
\end{abstract}

\section{S. F. R. Khadri}

khadrisfr@rediffmail.com

1 Department of Geology, Sant Gadge Baba Amravati University, Amravati, MS 446002, India hydraulic properties and sources) defined for the modelled area. Groundwater models play an important role in the development and management of groundwater resources, and in predicting effects of management measures. With rapid increases in computation power and the wide availability of computers and model software, groundwater modelling has become a standard tool for professional hydrogeologists to effectively perform most tasks. Then, boundary conditions are adjusted with the aid of a scattergram to reduce bias of the simulated hydraulic head distribution of the equivalent homogeneous aquifer. The differences between the simulated mean hydraulic head and the observed hydraulic head, resulting from small-scale heterogeneities are then reduced by adjustment of local transmissivity values based on the hydrological and geological information. The results of this case study, which produced a number of reasonable as well as some unsatisfying simulations, demonstrate the potential of coupling a surface water model and a groundwater model to obtain more complex and accurate analyses and simulations of hydrologic systems. This paper presents the results of a mathematical groundwater model developed for the Mahesh River basin in the Akola and Buldhana districts, employing conceptual groundwater modelling approach. For this purpose, groundwater modelling software (GMS) was used which supports the Visual Modular three Dimensional Flow-20011 code. For the purpose of modelling the source/ sink coverage, recharge coverage, extraction coverage, return flow coverage and soil coverage were considered. The model was calibrated against the historical and observed water level data for the period of 2013 and 2014.

Keywords Groundwater modelling flow $\cdot$ Visual MODFLOW software - GPS · Pumping and head observation wells and aquifer 


\section{Introduction of MODFLOW}

Nowadays, the numerical modeling technology has become an important method on the groundwater research. And many visual numerical modeling software of groundwater based on different methods have been developed and used widely such as Finite Element subsurface FLOW system (FEFLOW) (Diersch 2009), groundwater modeling system (GMS) (Anon 2000), Visual Modular three Dimensional Flow (Visual MODFLOW) (Anon 2000), a 2D and 3D geostatistics, uncertainty analysis and visualization software package (UNCERT) (Wingle et al. 1999) and Processing MODFLOW for Window (PMWIN, Chiang 2005). Of them, MODFLW (McDonald and Harbaugh 1988) was used as calculation program broadly because of its simple methods, modular program structure and separate package to resolve special hydrogeologic problems. For example, the popular software of GMS, Visual MODFLOW and PMWIN were all developed based on MODFLOW program. Combing with GIS technology they provided good visualization interface for user and played a significant role in the groundwater evaluation and management of many countries. From now on, many 2-D or 3-D groundwater flow quantity and quality models have been constructed successfully to resolve many groundwater flow problems.

Water being a universal solvent has been and is being utilized by mankind time and now. The fresh water is a finite and limited resource. Out of the total global water, only $2.4 \%$ is distributed on the main land, of which only a small portion can be utilized as fresh water. The available fresh water to main is hardly $0.3-0.5 \%$ of the total water available on the earth and therefore, its judicious use is imperative. The utilization of water from ages has led to its over exploitation coupled with the growing population along with improved standard of living as a consequence of technological innovations. Ground water is a precious and valuable natural gift is an important renewable resource having several advantages over surface water sources. It provides freshwater for domestic, agriculture, industrial and ecological purpose. However, due to the rapid economic development and population growth, the pressure imposed on ground water is alarmingly increasing. Also heavy ground water extraction has caused many problems such as decline in ground water level, salt water intrusion, ground water pollution, etc. among these problems ground water survival. Therefore the identification, assessment and remediation of ground water pollution have attracted the researcher and academician these days. The scale and degree of degradation varies significantly with the susceptibility of local aquifers to exploitation related deterioration and their vulnerability to pollution.Over $50 \%$ of the world's population is estimated to be residing in urban areas, and almost $50 \%$ of the mega-cities having populations over 10 million are heavily dependent on ground water, and all are in the developing world. In India, there are over 20 million private wells, in addition to the government tube wells Datta (2002). Thus the entire water demand has to be met from the groundwater as the rainfall is generally low and erratic and there is no perennial surface water system. We have attempted a mathematical modelling study of groundwater basin to assess its potential and for evolving utilization schemes (Gupta and Thangarajan 1990). The large-scale need for food security and urban drinking water supply is dependent on groundwater. The dependency becomes acute particularly during summer, when demand of water for different purposes increases dramatically as compared to not so elastic supply position. This grim situation is likely to aggravate further with rapid growth in population, urbanization and industrialization. Hydrologic cycle mainly deals with atmospheric, surface and ground waters. The largest source of available fresh water lies under ground. Ground water is the most important natural resource required for drinking, irrigation and industrialization. The resource can be optimally used and sustained only when the quantity and quality of ground water are assessed. The delayed-yield solution for unconfined flow to a well was originally obtained from an equation that was postulated empirically by Boulton (1954, 1963). A number of years later, Boulton (1973) and Cooley and Case (1973) showed that this solution can be interpreted as horizontal flow to a well in an aquifer underlain by an aquiclude and overlain by an aquitard containing a free surface. Flow in the aquitard was considered vertical and incompressible, and the delayed-yield effect resulted from vertical drainage through the overlying aquitard as the free surface drawdown. Groundwater flow models are beneficial for the management of groundwater resources as they give an approximate estimate about the various hydro-geological parameters. They also help in illustrating a clear picture of the flow pattern in an aquifer. Groundwater has become a highly dependent source of water. Low risk of contamination and its wide distribution make it more preferable than surface water. Groundwater modeling has emerged as an important tool for collecting various databases of an aquifer. Hence, groundwater modeling studies have enabled researchers to develop a better understanding of the functioning of aquifers and to water demand for industrial, agricultural and domestic uses is continuously degradation. It is, thus, imperative to manage the groundwater resources in an optimal manner. Management schemes can be evolved, only if the groundwater potential is assessed in more realistic manner. Mathematical modeling in conjunction with detailed field investigations has been proved to be a potential tool for this purpose. Evolving pre- 
development management schemes still works out to be better choice. One such study was carried out Mahesh River basin, Maharashtra, India With rapid increases in computational ability and wide availability of computers and model softwares groundwater modeling has become a standard tool for effective groundwater management. The study proceeded with the development of the conceptual model of regional groundwater flow. The calibration of the model parameters was conducted under steady-state flow and Transient state conditions. The numerical model was then used to simulate the groundwater flow under the current stress conditions. A steady state finite difference model, MODFLOW, is developed to quantify groundwater in Mahesh River basin, Maharashtra, India using ground water data from five pumping well and five head observation wells. The model simulates groundwater flow over an area of $328.25 \mathrm{~km}^{2}$ with 50 rows and 40 columns, with a single vertical layer. The model was calibrated for steady and transient state conditions. There was a reasonable match between the computed and observed heads. The transient model will run until the year 2016 to forecast the dynamic groundwater flow under various scenarios of over pumping and less recharge. The model predicts the behavior of this aquifer system under various hydrological stress conditions. The results indicate that the aquifer system is stable under the present conditions. A model with one layers flow regime was conceptualized by making use of available data. Mathematical model of the basin was constructed and calibrated for steady state condition by using Visual MODFLOW computer software. This simulation study indicates that substantial development of groundwater potential is possible in this area. Result shows that the computed groundwater level contours are in good agreement with observed ones and head observation and calculated observation. The simulated water levels using MODFLOW were compared with observed water levels. The hydraulic heads of simulated and observed values showed a reasonably good correlation and same model can be used for the prediction of ground water levels in future and also estimation of groundwater for the further developmental activities in this zone. The study presented herein used processing MODFLOW to construct a groundwater flow model in the basin. The calibration of the model parameters was conducted under steady-state flow conditions. The numerical model was then used to simulate the groundwater flow under the current stress conditions.

\section{Calibration criteria}

Model calibration may be viewed as an evolutionary process in which successive adjustments and modifications to the model are based on the results of previous simulations. The modeller must decide when sufficient adjustments have been made to the representation of parameters and processes and at some time accept the model as being adequately calibrated (or perhaps reject the model as being inadequate and seek alternative approaches). This decision is often based on a mix of subjective and objective criteria. The achievement of a best fit between values of observed and computed variables is a regression procedure and can be evaluated as such. That is, the residual errors should have a mean that approaches zero and the deviations should be minimised. Cooley (1977) discusses several statistical measures that can be used to assess the reliability and "goodness of fit" of groundwater flow models. The accuracy tests should be applied to as many dependent variables as possible. The types of observed data that are most valuable for model calibration include head and concentration changes over space and time, and the quantity and quality of groundwater discharges from the aquifer.

\section{Model validation}

It is natural for people who apply groundwater models, as well as those who make decisions based on model results, to want assurance that the model is valid. Groundwater models are embodiments of various scientific theories and hypotheses. Popper (1959) argues that "as scientists we can never validate a hypothesis, only invalidate it". The same philosophy has been applied specifically to groundwater models (Konikow and Bredehoeft 1992; Oreskes et al. 1994). The criteria for labelling a model as validated are inherently subjective. In practice, validation is attempted through the same process that is typically and more correctly identified as calibration-that is, by comparing calculations with field or laboratory measurements. However, the non-uniqueness of model solutions means that a good comparison can be achieved with an inadequate or erroneous model. Also, because the definition of "good" is subjective, under the common operational definitions of validation, one competent and reasonable scientist may declare a model as validated while another may use the same data to demonstrate that the model is invalid. To the general public, proclaiming that a groundwater model is validated carries with it an aura of correctness that many modellers would not claim (Bredehoeft and Konikow 1993). Because labelling a model as having been "validated" has very little objective or scientific meaning, such "certification" does little beyond instilling a false sense of confidence in such models. Konikow and Bredehoeft (1992) has recommend that the term validation not be applied to groundwater models. 


\section{Hydrogeological system}

Generally, the entire area of study is traversed by Deccan trap rock formations. The occurrence and movement of groundwater in hard rock formations are restricted to open systems of fracture like fissures and joints in non-weathered portions and also in the porous zone of weathered formations. In hard rock regions, the weathered thickness is discontinuous both in space and depth. Hence, the recharge of groundwater in hard rock formation is influenced by the intensity of weathering. On the basis of geological formations, the entire state of Maharashtra can be divided into five groundwater provinces. Precambrian consolidated and compact sedimentary rock province, Gondwana consolidated rock province, Deccan trap lava flows and alluvial unconsolidated sedimentary rock province. The Deccan trap which occupies more than $81 \%$ of the area of the state is a major groundwater province for consideration and estimation of groundwater potential of the state. The basaltic lava flow occurs as a widely spread sheet of basic rocks forming extensive plains. The entire pile of lava flows shows variation in their physical character, storing and transmitting groundwater and thus its hydrological properties are differs from the other. The subsurface condition was analyzed from borehole lithology and pumps test data. Borehole lithology revealed that the thickness of the aquifer in the study area is highly erratic and varies between 6 and $15 \mathrm{~m}$ below ground level.

\section{Study area}

The Mahesh River basin is situated in Akola and Buldhana Districts of Maharashtra which is located between $76^{\circ} 46^{\prime} 11^{\prime \prime} \mathrm{E}$ and longitude $20^{\circ} 40^{\prime} 36^{\prime \prime} \mathrm{N}$ latitude covered by survey of India toposheets no. 55 D/9, 55 D/7, 55 D/11, 55 $\mathrm{D} / 13,55 \mathrm{D} / 14$ and $55 \mathrm{D} / 15$ on 1:50000 scale. The Mahesh River basin which is a major tributary of Mun River lies towards the western and southern part of Akola and Buldhana district. The total area covered by Mahesh River basin is $328.25 \mathrm{~km}^{2}$. The study area is occupied by alluvium and Deccan basalts which are horizontally disposed and is traversed by well-developed sets of joints. The Ajanta hill ranges are bordering the district in the southern with their slope towards western. The starting part of Akola district is plain whereas the western part is again elevated with its general slope towards southern. The Mahesh River basin flows in the southern to western direction having western slope and meets the Mun River near Balapur village in Akola districts. Purna is the major river of the Akola and Buldhana districts. The important tributaries of Purna River are Katepurna, Morna, Man, Vidrupa, Shahanur, Van and Nirguna. Most of the watershed area was covered by unconsolidated sediments, black cotton soil, red soils and basaltic rocks of Deccan traps. The study area was drained by Mahesh River basin flowing south to western with almost dendritic to sub-dendritic drainage pattern (Fig. 1).

\section{Data collection}

Data collection is another important component in the model development process. In the present study, data are collected from GSDA and CGWB. The data include hydrological, hydrogeological, rainfall and well data. After thorough study of the existing data and reports, a field reconnaissance survey was carried out to have a complete understanding of site hydrogeology and information on the Mahesh River basin Akola and Buldhana districts, Maharashtra, India.

\section{Geology and geomorphology}

The geology of the study area is classified into hard rock formations. More than $95 \%$ of the Akola and Buldhana districts is underlain by hard rock. The Atali, Lokhanda and Amdapur formation is the major formation among the various types of hard rocks. Recent alluvial deposits such as sand, silt, clay, gravel, etc. which are transported sediments by river are found on either side of Mahesh River basin in Balapur Taluka. These formations are overlying the hard rock. The southern part of the Akola and Buldhana districts is occupied by Purna alluvium which is saline in nature. Purna lineament marks the northern part of the basin and the southern part was delineated by Kaddam lineament trending NW-SE and extends up to $280 \mathrm{~km}$ and that was named after Kaddam River whose course has controlled by this fault lineament. In the present study south part mostly cover of open scrub forest, reserved forest, scrub land and hilly area in southern part. Physiographically, the area consists of minor depositional and majority of erosional landforms, the topography is characterized by the presence various landforms like mesa, butte, moderately dissected, pediment and pediplain. Soil characteristics of a terrain are important since they meet the basic needs of all agricultural production. Different soils that occur are derived from a wide range of geological materials.

\section{Drainage system}

Drainage pattern is one of the most important indicators of hydrogeological features since it is controlled by underlying lithology. The drainage pattern and texture seen on aerial photographs/satellite imageries are the indicators of landform and bedrock type and also suggest soil characteristics and site drainage condition. In addition, the stream 


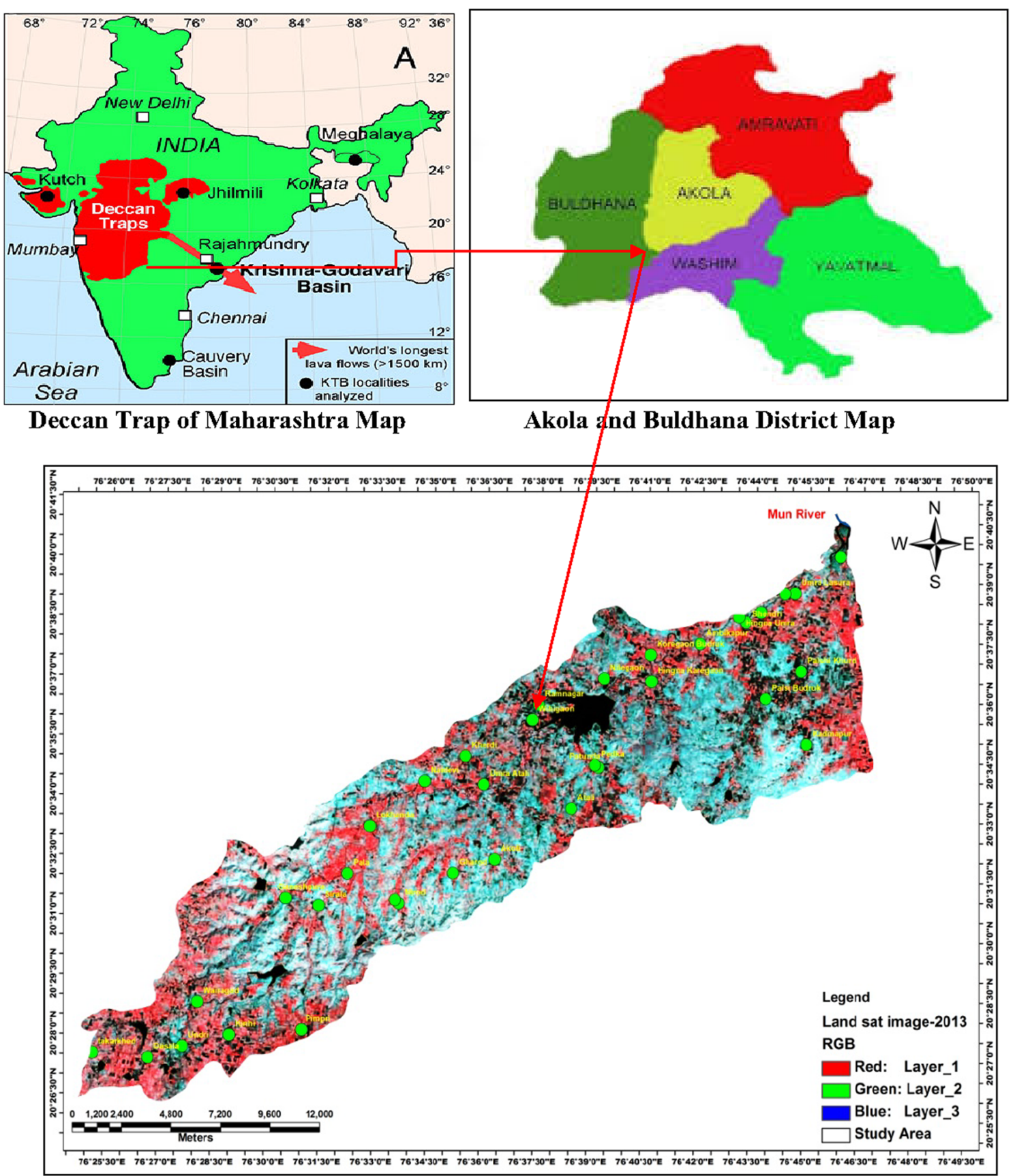

Fig. 1 Location map of Mahesh River basin

pattern is a reflection of the rate at which precipitation infiltrates in comparison with the surface runoff. The infiltration/runoff relationship is controlled largely by permeability, which is, in turn, a function of the type and fracturing of the underlying rock or surface bedrock. When comparing two terrain types, the one that contains the greatest drainage density is usually less permeable. A welldeveloped dendritic to sub-dendritic drainage system is generally noticed in the basin which indicates the occurrence of rocks of uniform resistance.

\section{Hydrogeomorphology}

It is possible to delineate various hydrogeomorphic units from satellite imageries through visual interpretation. Groundwater recharge, transmission and discharge of the basin are controlled by the basin geomorphology, geology and structural patterns. Hydro-geomorphological maps help to identify the various geomorphic units and groundwater occurrence in each unit. Hydro-geomorphological map of the study area was prepared from the IRS-1D-LISS- 
III satellite imageries. The various geomorphic units as identified from the studies are structural hills, residual hills, valley fills, uplands, pediments and bajadas. It is seen that structural and denudational process controls influence the fluvial processes in this region.

\section{Water level data}

Ground levels were measured monthly for 2 years (2013-2014) at five pumping test and five observation wells. Water level fluctuations are found to vary from 3.0 to $10.9 \mathrm{~m}$. The well hydrographs indicates that there was no decline in water level for the period 2013-2014 because of very good monsoon, with average of 900 to $1000 \mathrm{~mm}$ during 2013-2014.

\section{Model design}

Equation 2 describes ground water flow under non-equilibrium conditions in a heterogeneous and an isotropic medium, provided the principal axes of hydraulic conductivity are aligned with the $x-y$ Cartesian coordinate axes. The groundwater flow equation together with specification of flow and/or initial head conditions at the boundaries constitutes a mathematical representation of the aquifer system. Numerical methods are generally used in solving the groundwater flow equation. The computer software mudflow developed by McDonald and Harbaugh of United States Geological Survey (USGS) (1988) was used for the present study. A pre- and post-model processor viz.

\section{Hydraulic conductivity}

In Visual MODFLOW 2011 software version hydraulic conductivity was the hydraulic conductivity along model rows. It was multiplied by an anisotropic factor to obtain the hydraulic conductivity along model columns. Table 1 shows the hydraulic conductivity of the model showing model properties of the aquifers in the area of investigation. For flow simulations involving more than one layer, MODFLOW required the input of vertical transmission or leakage term, known as vertical leakance between two model layers. The software took the vertical hydraulic conductivities and thickness of layers to calculate the vertical leakance.

\section{Effective porosity}

Effective porosity is virtually equal to the specific yield when the compressibility is ignored. This parameter is used in the MODFLOW to calculate the average velocity of flow through the porous medium. With the available literature
Table 1 Aquifer properties

\begin{tabular}{lll}
\hline $\begin{array}{l}\text { Sr. } \\
\text { no. }\end{array}$ & Model properties & $\begin{array}{l}\text { Hydraulic conductivity } \\
\left(K_{x} \text { in } \mathrm{m} / \text { day }\right)\end{array}$ \\
\hline 1 & $\begin{array}{l}\text { Hydraulic conductivity in } \\
\text { longitudinal direction }\left(K_{x} \mathrm{~m} / \mathrm{s}\right)\end{array}$ & 0.000015 \\
2 & $\begin{array}{c}\text { Hydraulic conductivity in lateral } \\
\text { direction }\left(K_{y} \mathrm{~m} / \mathrm{s}\right)\end{array}$ & 0.000014 \\
3 & $\begin{array}{l}\text { Hydraulic conductivity in vertical } \\
\text { direction }\left(K_{z} \mathrm{~m} / \mathrm{s}\right)\end{array}$ & $1.2 \mathrm{e}-4$ \\
4 & Specific yield $(\mathrm{Sy})$ & 0.0022 \\
5 & Effective porosity & 0.15 \\
6 & Total porosity & 0.30 \\
7 & Transmissivity $\left(\mathrm{m}^{2} / \mathrm{s}\right)$ & $7.2 \mathrm{e}-4$ \\
8 & Specific storage $\mathrm{Ss}(1 / \mathrm{m})$ & $1 \mathrm{e}-4$ \\
\hline
\end{tabular}

and the GSDA, CGWB study reports, the aquifer properties are assigned in the model as follows (Table 1).

\section{Initial heads}

For steady state simulation, MODFLOW needs an initial guess for the head distribution and for a transient simulation it needs a starting head distribution. The drawdown is also calculated from the initial head. The initial head is assigned based on the water level data obtained from GSDA and CGWB (Table 1).

\section{Groundwater flow processes: governing equations}

The subsurface environment constitutes a complex, three dimensional heterogeneous hydrogeological setting. The variability strongly influences groundwater flow and such a reality can be described accurately only through careful hydrogeological practice. Mathematical equations that describe groundwater flow may be developed from the fundamental principle of conservation of mass of fluid. Given a representative elementary volume (REV) of porous medium, a general equation for conservation of mass for the volume is expressed as:

Rate of inflow - Rate of outflow $=$ Rate of change

Mathematically stated, it is,

$Q=-k i A$

where $Q$ is the discharge, $K$ the hydraulic conductivity, $I$ the hydraulic gradient and $A$ is the area of flow.

A general groundwater flow equation may be written in Cartesian form as:

$\frac{\delta}{\delta_{x i}}\left(k_{i j} \frac{\delta h}{\delta_{x i}}\right)=S \frac{\delta h}{\delta t}+W$

where $S$ is the specific storage, $\mathrm{L}^{-1} ; W$ the volumetric flux per unit volume ( - for outflow and + for inflow), $\mathrm{T}^{-1}$; and $K$ is the hydraulic conductivity. 


\section{Over view of Visual MODFLOW}

Visual MODFLOW is the proven standard for professional 3-D groundwater flow and contaminant transport modeling. Visual MODFLOW combines the most powerful and intuitive interface available with the latest versions of MODFLOW, MODPATH, Zone Budget and MT3D. Visual MODFLOW can be applied for (a) evaluate groundwater remediation systems, (b) delineate well capture zones, (c) simulate natural attenuation of contaminated groundwater, (d) estimate the reductive dechlorination of trichloroethylene and polychloro-ethylene in groundwater, (e) design and optimize pumping well locations for dewatering projects, (f) determine contaminant fate and exposure pathways for risk assessment. The Visual MODFLOW interface has been specifically designed to increase modeling productivity and decrease the complexities typically associated with building three-dimensional groundwater flow and contaminant transport models. The interface is divided into three separate modules viz., input module, run module and output module.

\section{MODFLOW software}

MODFLOW is a computer program that numerically solves the ground-water flow equation for a porous medium by using a finite-difference method and is developed by US Geological Survey. The software is used primarily by hydrogeologists to simulate groundwater flow and contaminant transport. MODFLOW was designed such that the user can select a series of modules to be used during a given simulation. Each module deals with a specific feature of the hydrologic system (e.g. wells, recharge and surface water bodies). The choice between analytical and numerical models is somewhat crucial and depends on the complexity of hydrogeological conditions and the availability of field data. Keeping this in view, in the present study, a numerical model for the solution of groundwater flows is developed.

\section{MODFLOW}

MODFLOW, 'a three-dimensional finite-difference groundwater flow model' by Michael G. Mcdonald and Arlen W. Harbaugh, is the most widely used groundwater model in the world. The MODFLOW program is based on finite difference method. Figure 1 shows the discrimination of continuous medium into finite difference cells. Groundwater flow within the aquifer is simulated in MODFLOW using block centred finite-difference approach. Layer can be simulated as confined, unconfined, or a combination of both. Flows from external stress such as flow to wells, areal recharge, evapotranspiration, flow to drains and flow through riverbeds can also be simulated. A large amount of information and a complete description of the flow system are required to make the most efficient use of MODFLOW. To use MODFLOW, the region to be simulated must be divided into cells with a rectilinear grid resulting in layers, rows and columns. Files must be prepared that contain hydraulic parameters (hydraulic conductivity, transmissivity, specific yield, specific storage, etc.), boundary conditions (location of impermeable boundaries and constant heads) and stress (pumping wells, recharge from precipitation, rivers, drains, evapotranspiration, etc.).

\section{Model calibration}

Model calibration consists of changing values of model input parameters in an attempt to match field conditions within some acceptable criteria. This requires that field conditions at a site be properly characterized. Lack of proper site characterization may result in a model that is calibrated to a set of conditions which are not representative of actual field conditions. The calibration process typically involves calibrating to steady-state and transient conditions. With steady-state simulations, there are no observed changes in hydraulic head or contaminant concentration with time for the field conditions being modeled. Transient simulations involve the change in hydraulic head or contaminant concentration with time (e.g. aquifer test, an aquifer stressed by a well-field, or a migrating contaminant plume). These simulations are needed to narrow the range of variability in model input data since there are numerous choices of model input data values which may result in similar steady-state simulations. Models may be calibrated without simulating steady-state flow conditions. At a minimum, model calibration should include comparisons between model-simulated conditions and field conditions for the following data: hydraulic head data, groundwater-flow direction, hydraulic-head gradient, water mass balance, contaminant concentrations (if appropriate), contaminant migration rates (if appropriate), migration directions (if appropriate), and degradation rates (if appropriate). These comparisons should be presented in maps, tables, or graphs. There are no universally accepted "goodness-of-fit" criteria that apply in all cases. However, it is important that the modeler make every attempt to 40 minimize the difference between model simulations and measured field conditions. Typically, the difference between simulated and actual field conditions (residual) should be $<10 \%$ of the variability in the field data across the model domain. 


\section{MODFLOW input}

\section{Base map}

Visual MODFLOW supports the use of base maps in all modules of the program. Mahesh River basin map obtained from SOI toposheets is taken as base map. It is scanned and converted in *.BMP format. Base map is imported into the model screen. Model co-ordinates are fixed by taking $x 1$, $y 1$ co-ordinates as $(0,0 \mathrm{~m})$ at the point of entry of Mahesh River basin into the Akola and Buldhana district. $x 1, y 1$

Table 2 Comparative study of observed vs. calibrated head values at 365.2 days

\begin{tabular}{lll}
\hline Well no. & $\begin{array}{l}\text { Observed head } \\
\text { (traditional values) } \\
\text { (input data) }\end{array}$ & $\begin{array}{l}\text { Calculated head } \\
\text { (calibrated values) } \\
\text { (output data) }\end{array}$ \\
\hline OB1 & 9.50 & 9.65 \\
OB2 & 9.60 & 9.77 \\
OB3 & 9.65 & 9.88 \\
OB4 & 9.83 & 9.93 \\
OB5 & 9.45 & 9.93 \\
\hline
\end{tabular}

coordinate corresponds to $76^{\circ} 46^{\prime} 11^{\prime \prime} \mathrm{E}$ and longitude $20^{\circ} 40^{\prime} 36^{\prime \prime} \mathrm{N}$ latitude, respectively. The river flow is from southwest to northeast (Table 2).

\section{Boundary conditions}

The groundwater divide in the area coincides with the topographic divide (CGWB-CAG Terminal Report 1997). The drainage map of the area is shown in Fig. 2. The basin is regarded as a closed one with no flow across the boundaries except outflow through a small section in the eastern boundary. There are however, a few ephemeral surface streams, which take off the groundwater effluence across the eastern boundary of the area, during the monsoon season. The aquifer has been assumed to be a single layer aquifer having a vertical recharge and has been modeled accordingly. The bottom of the aquifer is assumed to be impermeable bedrock. The numerical model was then used to simulate the groundwater flow under the current stress conditions. A steady state finite difference model, MODFLOW, is developed to quantify groundwater in Mahesh River basin, Maharashtra, India using ground water data from five pumping well and five head observation wells. The model simulates groundwater flow over
Fig. 2 Base map of Mahesh River basin

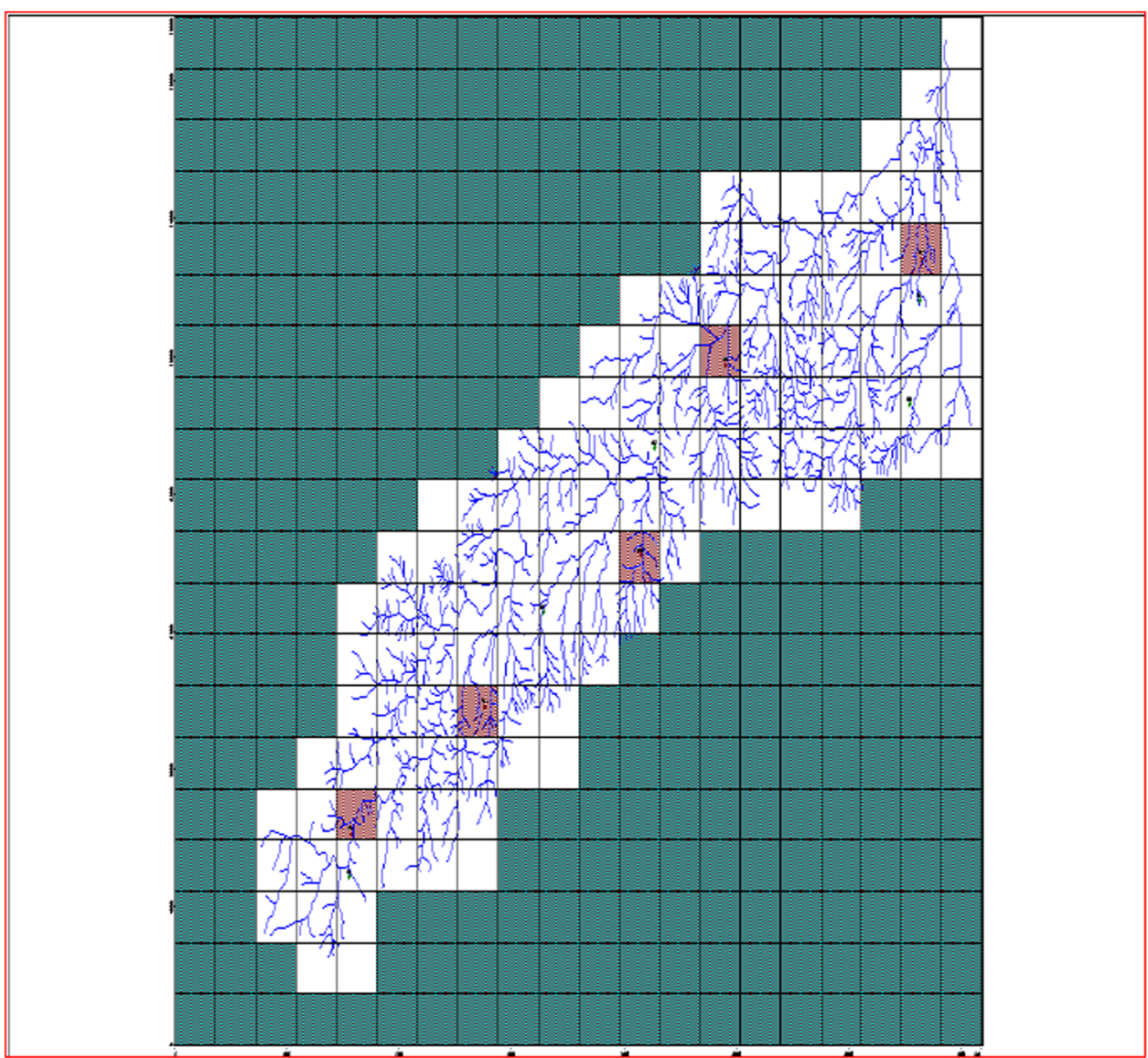


Fig. 3 Active flow and nonactive flow of Mahesh River basin

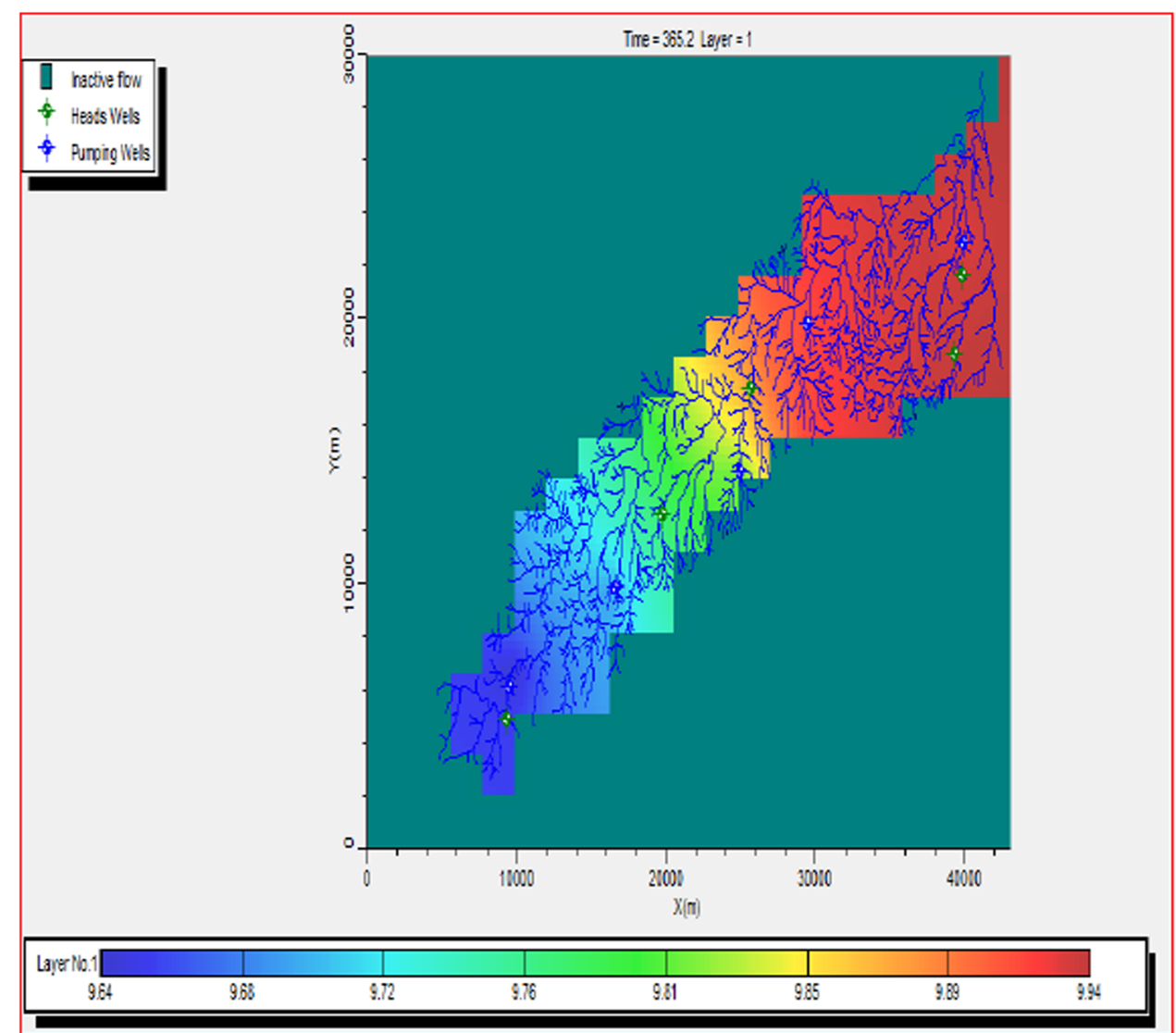

an area of $328.25 \mathrm{~km}^{2}$ with 50 rows and 40 columns, with a single vertical layer. Based upon lithology, water levels aquifer was conceptualised as unconfined of single layer. The initial hydraulic head was given based on the observed water levels of 2013 and 2014 year (Figs. 3, 4, 5).

\section{Procedure for ground water flow model}

As a first step, database had to be established which includes bore hole details for wells, physical parameters such as hydraulic conductivity, storage co-efficient, pumping data, well observation data and time series data on rainfall, water levels data for the period 2013-2014 from observation wells. The complete procedure for ground water flow model shown in the form flowcharts (Figs. 4, 7).

\section{Model conceptualization}

The conceptual model of the system was arrived at from the detailed studies of geology, borehole lithology and water level fluctuations in wells. Groundwater of the study area was found to occur in weathered rocks. The groundwater head in wells penetrating only up to the weathered formation as well as in wells penetrating up to the hard rock formation was more or less the same. Hence, the top soil and the lower weathered and fractured rocks could be considered as a single, unconfined aquifer.

\section{Wells}

In the well drop-down menu one can choose to graphically add, delete or edit pumping well, head observation wells, concentration observation wells. Visual MODFLOW allows inputting field observations for head, concentration and relating this observation to model output values (Fig. 5).

\section{Pumping wells}

Well inventory is made on entire stretch of study area (20 km stretch) and their pumping rate and their usage are calculated. There are four observation wells is carried out of study and calculated start time, end time and rate. By carrying of filed study and the available GSDA data it is calculated that the groundwater abstraction for irrigation and industries in the study area is about $15.66 \times 106 \mathrm{~m}^{3}$ per year. The pumping wells are located in the grid and the pumping rate is entered. Positive rates are used for 
Fig. 4 Flow chart for the flow model using MODFLOW

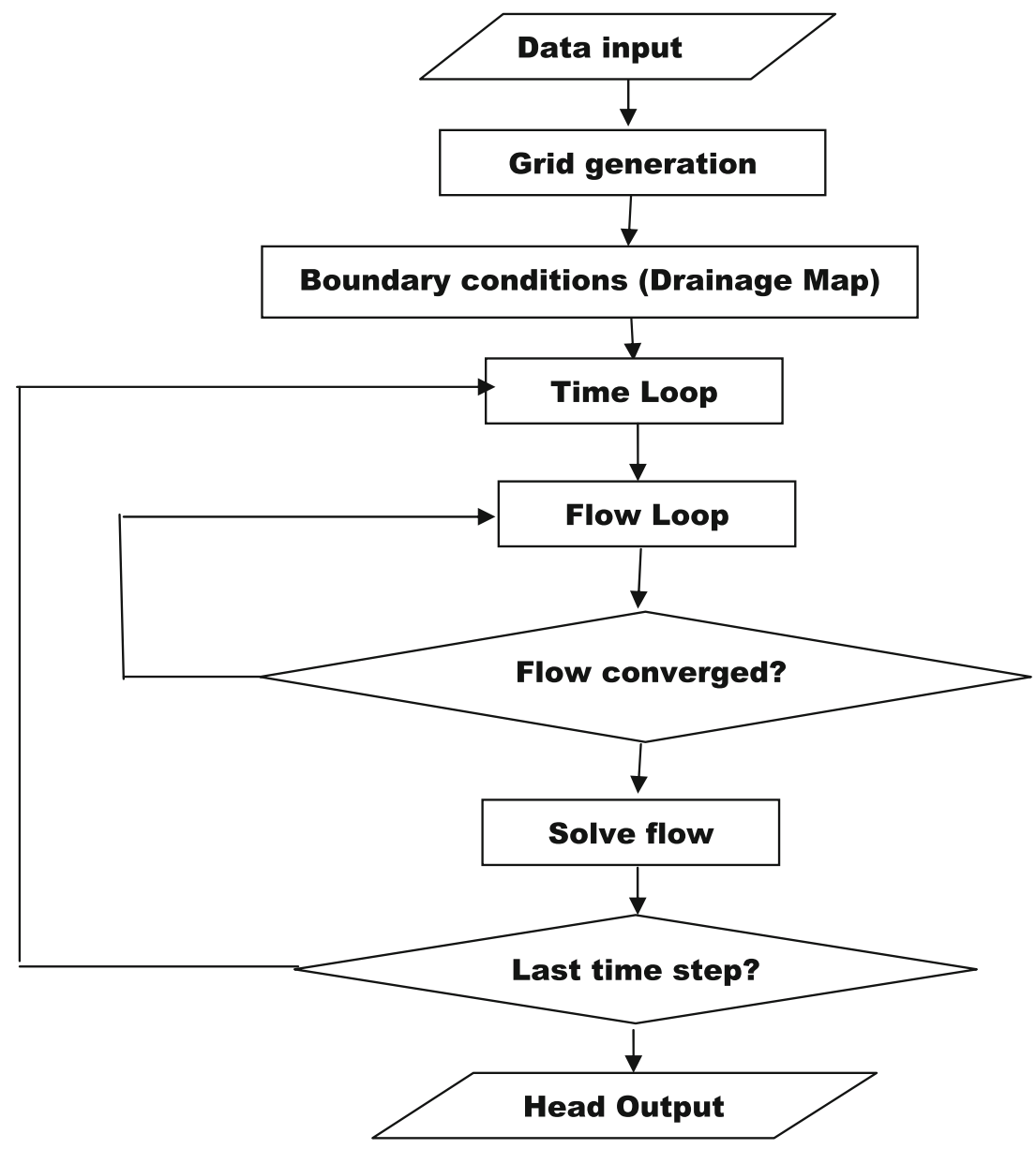

Fig. 5 Schematic diagram for the modeling procedure

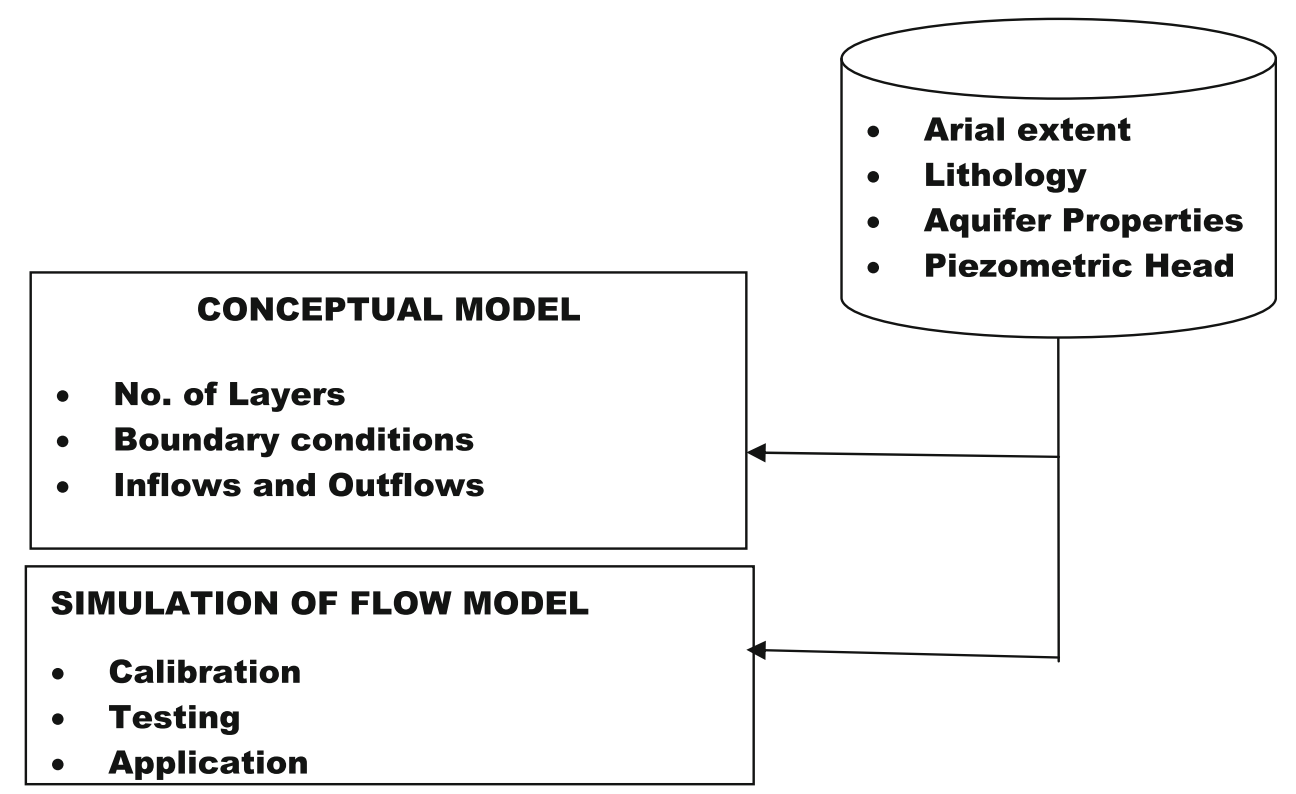




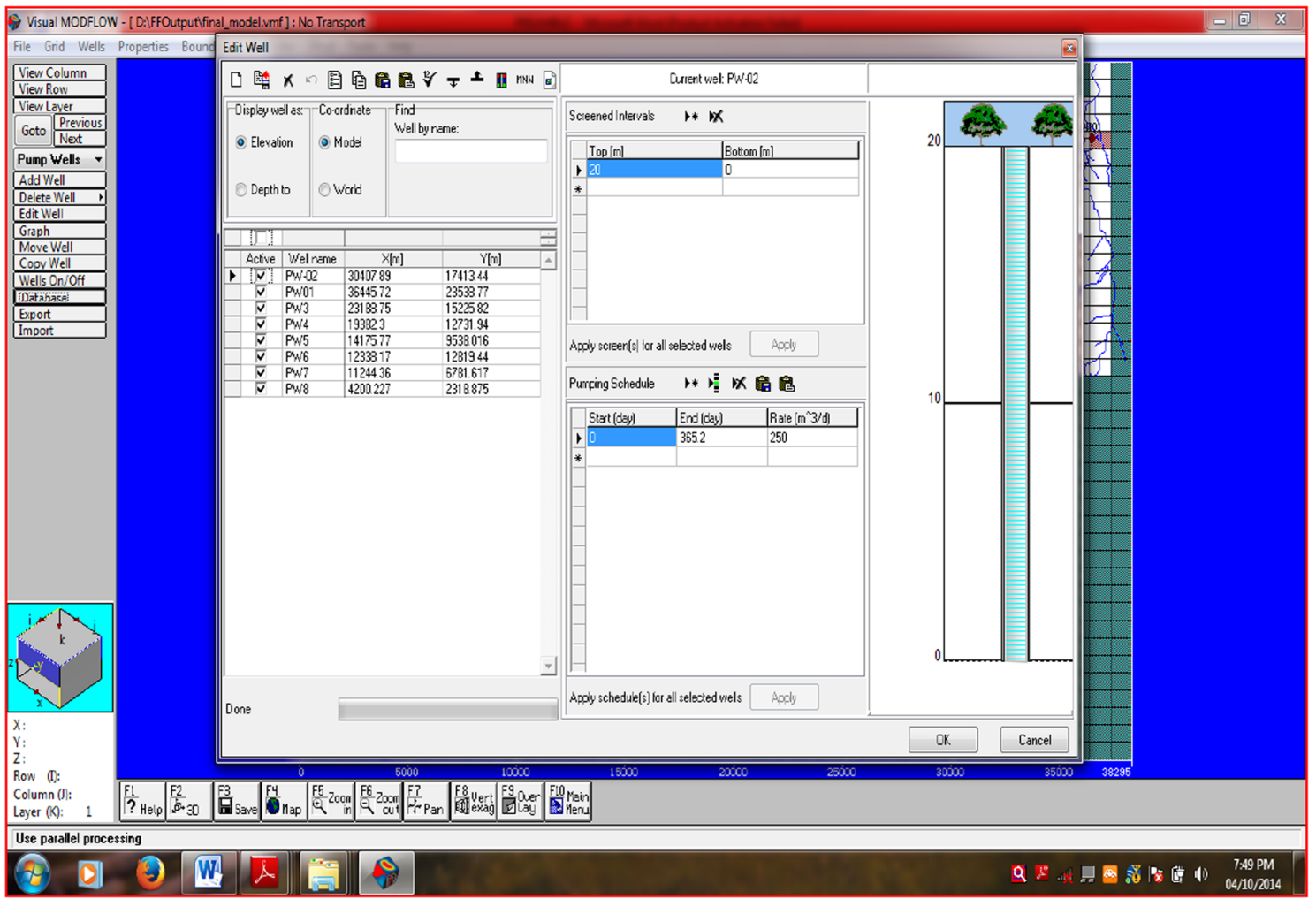

Fig. 6 Pumping well edit screen

injection. Negative rates are used for pumping. In the study area there is no injection wells. However, ground water recharge structures are construed by GSDA to capture run off during rain. These structures are taken into consideration in the model input. MODFLOW considers a well in a cell to be located at the centre of a cell. MODFLOW considers a well be screened across the entire layer it is located in, regardless of the screening interval assigned. The first pumping rate in the pumping schedule is used as the pumping rate for steady-state simulations. The pumping rate must be specified continuously for all stress periods. In a transient simulation, the pumping wells are turned off if the pumping rate is not specified for the later stress periods. If a well cell goes dry during a simulation, the pumping rate of the well at that location will automatically be reduced. By using copying well option multiple wells are located in the grid (Figs. 6,7).

\section{Head observation wells}

The Visual MODFLOW package saves the calculated heads at the locations of specified observation wells for every time step in a *.HVT (head vs. time) file. This allows the user to compare simulated heads with observed heads, produce calibration statistics, and produce hydrographs at observation wells without saving the entire MODFLOW solution at every time step. Observation well information is required for the calibration. Model saves hydraulic head and drawdown at every time step. The Groundwater Wing of State GSDA monitors groundwater level in three shallows open wells and two bore wells spread in the Mahesh River basin district on half yearly basis. Out of these five wells are falling within the study area. The location of these five wells (OW1-OW5) can be seen in the study area. A general observation of pumping data and water level data at monitoring wells, suggest that water tends to rise during the June-December to reach the highest peak and start declining from February onwards to end of August to September in each year. The rise and fall depend upon the amount, duration and intensity of rainfall, thickness of weathering, specific yield of the formation and general slope of the aquifer bottom towards the drainage channel. The GSDA monitoring wells are located in the grit using head observation wells menu and the water levels from year 2013 to 2014 are entered. However these well data are used for over all analysis. Head observation well edit screen is in Fig. 8.

\section{Sensitivity analysis}

A sensitivity analysis is the process of varying model input parameters over a reasonable range (range of uncertainty in values of model parameters) and observing the relative 


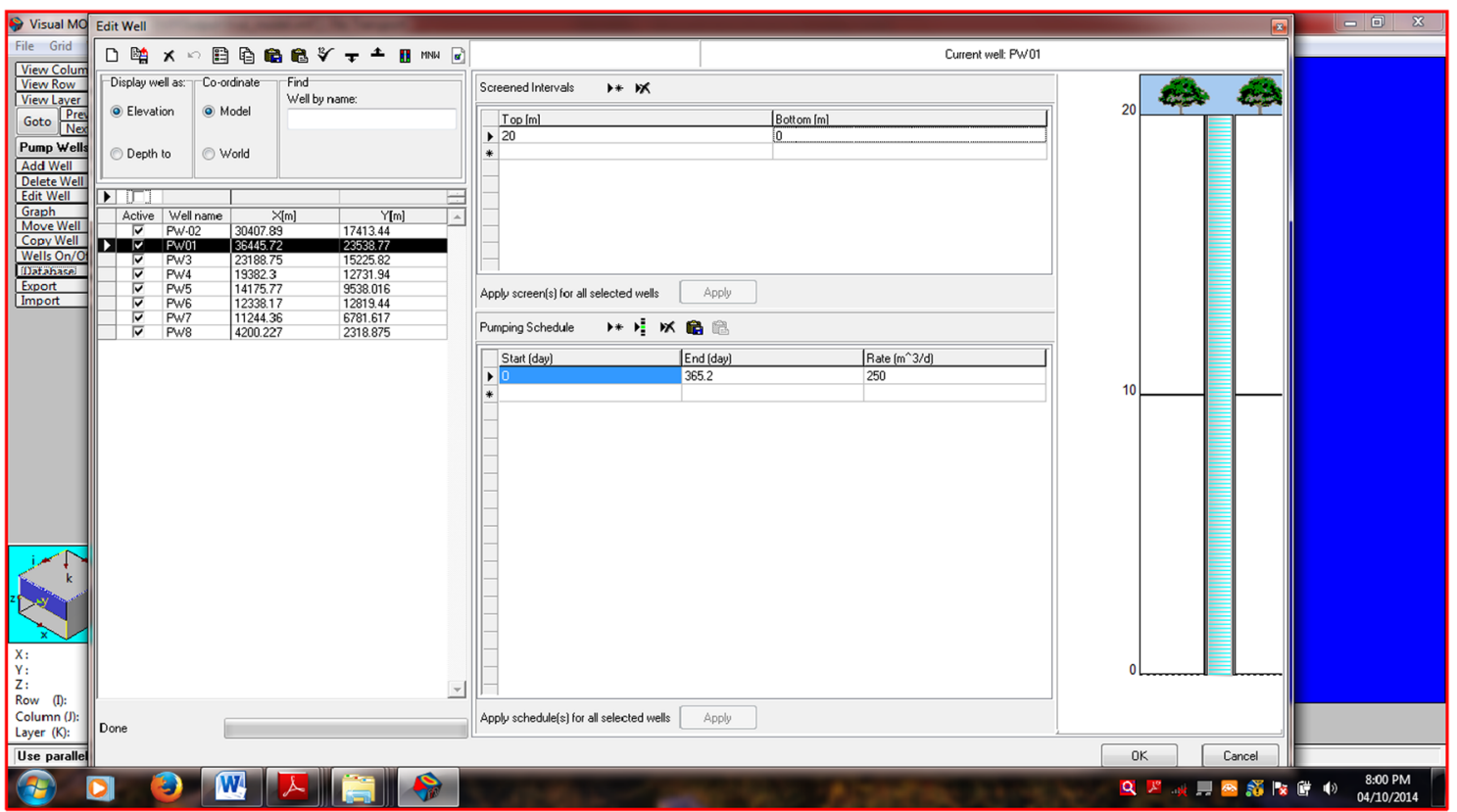

Fig. 7 Pumping well edit model

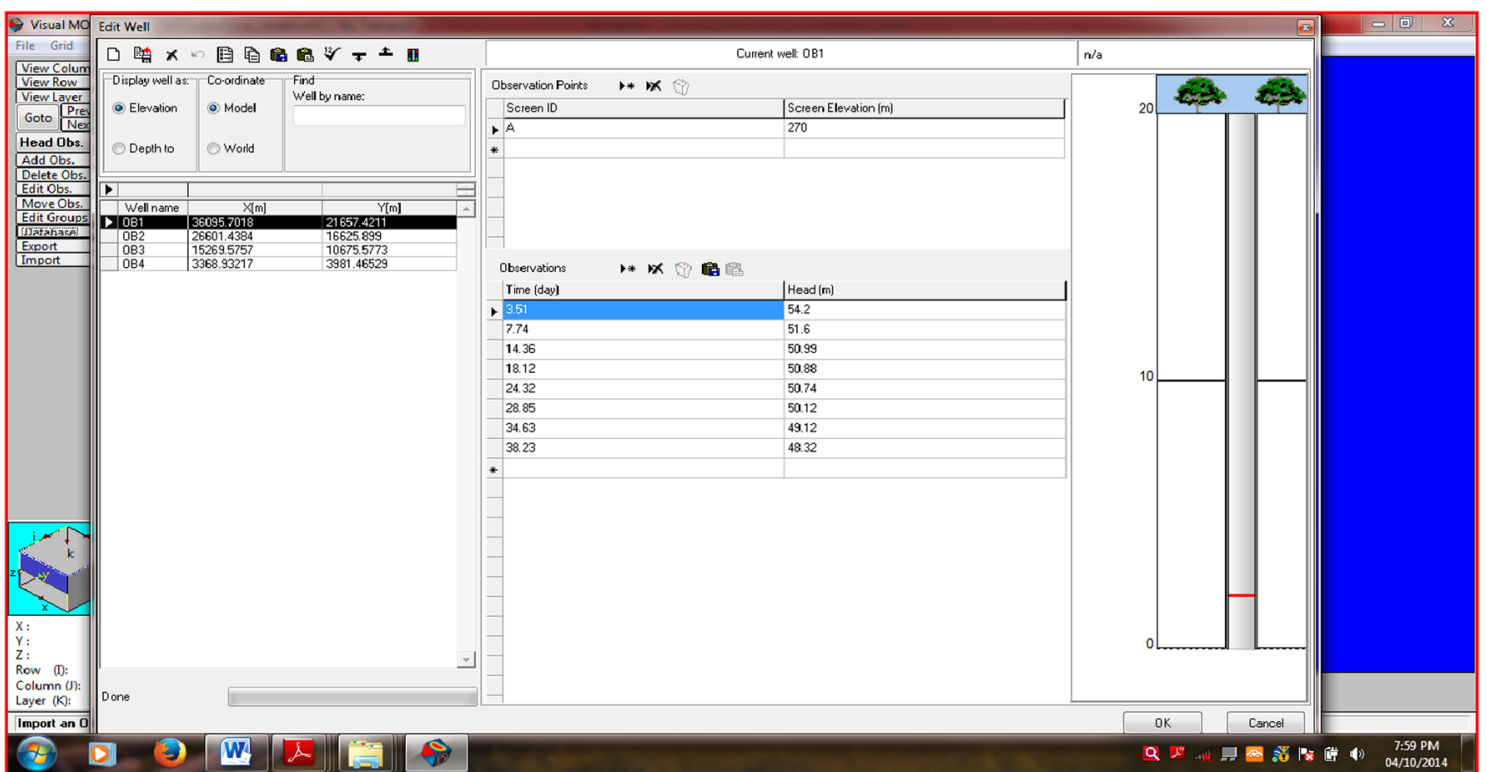

Fig. 8 Head observation well edit model

change in model response. Typically, the observed changes in hydraulic head, flow rate or contaminant transport are noted. The purpose of the sensitivity analysis is to demonstrate the sensitivity of the model simulations to uncertainty in values of model input data. The sensitivity of one model parameter relative to other parameters is also demonstrated. Sensitivity analyses are also beneficial in determining the direction of future data collection activities. Data for which the model is relatively sensitive would require future characterization, as opposed to data for which the model is relatively insensitive. Modeling sensitive data would not require further field characterization.

\section{MODFLOW run}

After completing the input parameters, run model is selected from the screen. By selecting run in the main menu, select run type dialogue box appears. Steady 
Fig. 9 Head vs. time for observation wells of Mahesh River basin

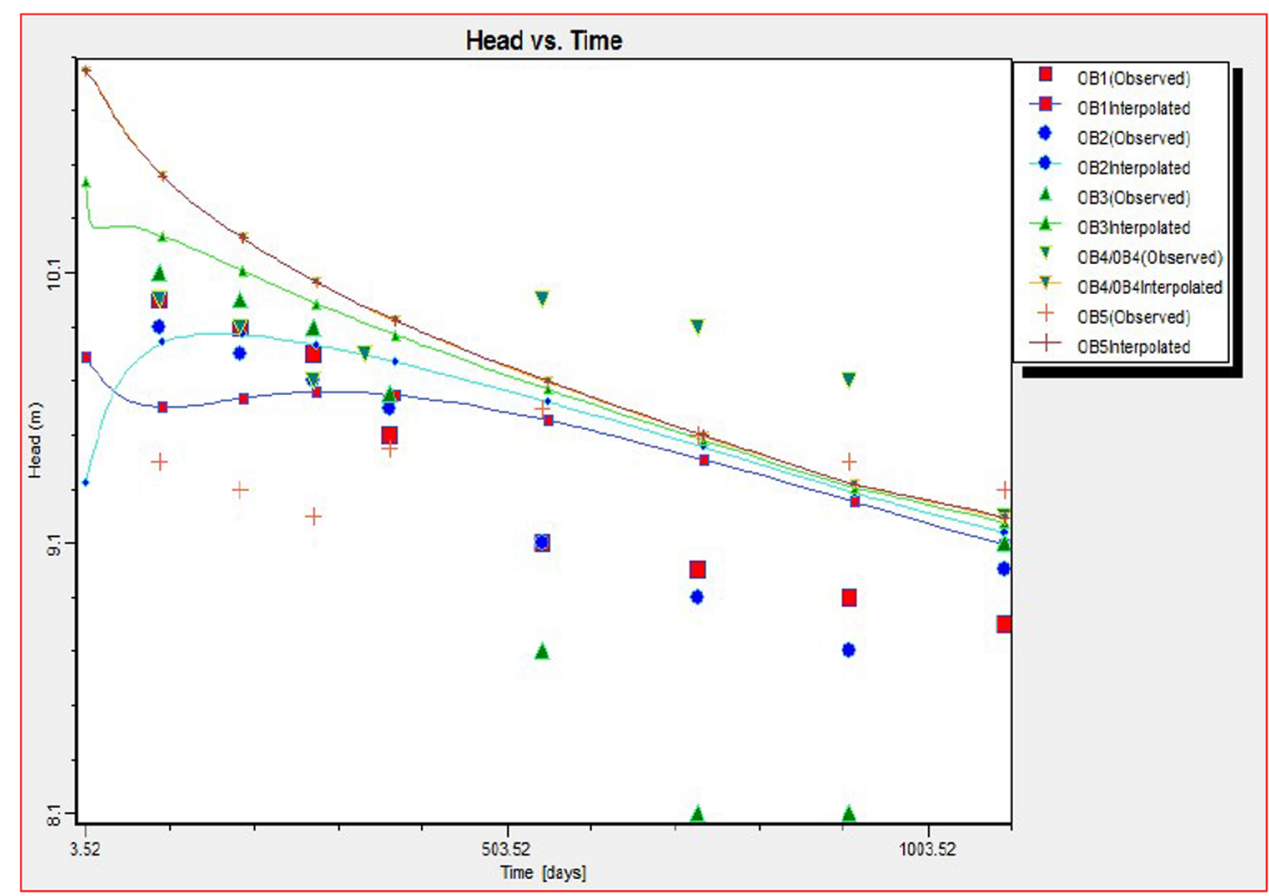

state and transient state run types are available in the model. First, the model was run for steady state condition. After that the model was run under transient condition. WHS solver was selected. The WHS solver works on a two-tier approach to a solution at one time step.

\section{Model design}

The computer software programme MODFLOW developed by the USGS (McDonald and Harbaugh 1988) was used for the present study. In this programme, using the Block Centre Finite Difference Approach solves groundwater flow equation. A pre- and post-model processor viz. Visual-MODFLOW developed by Nilson Guigner and Thomas Franz of Waterloo Hydrologic Software Inc. It was used for graphical data input, and for analysis and presentation of the output data.

\section{MODFLOW output}

MONDFLOW output provides contours of head equipotential, head difference, drawdown, elevation, net recharge, and water table. It also provides graphs of calculated vs. observed heads, calibration of residual histogram, head vs. time, normalized RMS vs. time, and drawdown vs. time. The model output also provides velocity vectors with direction of flow. By using the input and output screen the model is calibrated (Fig. 9).

\section{Model calibration}

Model calibration consists of changing values of model input parameters in an attempt to match field conditions within an acceptable criterion. Calibration is carried out by trial and error adjustment of parameters or by using an automated parameter estimation code. Model calibration requires that field conditions at a site be properly specified. Otherwise, model will not be a reliable representative of actual field conditions. After a number of trial runs, computed water levels were matched fairly reasonably with observed values. In the present study, during calibration, horizontal and vertical hydraulic conductivities and recharge values were adjusted in sequential model runs to match the simulated heads and measured heads.

\section{Steady state calibration}

The groundwater flow model has been constructed for computation of hydraulic head distribution. As minor fluctuation is observed in groundwater level in the area, this indicates that hydraulic gradients do not change significantly with time (Hani et al. 2007). Thus groundwater flow was assumed to be under steady state condition represented by groundwater condition of December 2013 and 2014. For steady state simulation five observation wells were included on the calculated versus observed heads graph (Figs. 10, 11; Tables 2, 3). The groundwater head in the aquifer model was computed by using Visual 
Fig. 10 Model calculated vs. filed observed at 365.2 days (January 2013)
Fig. 11 Model calculated vs. filed observed at 1095 days (January 2014)
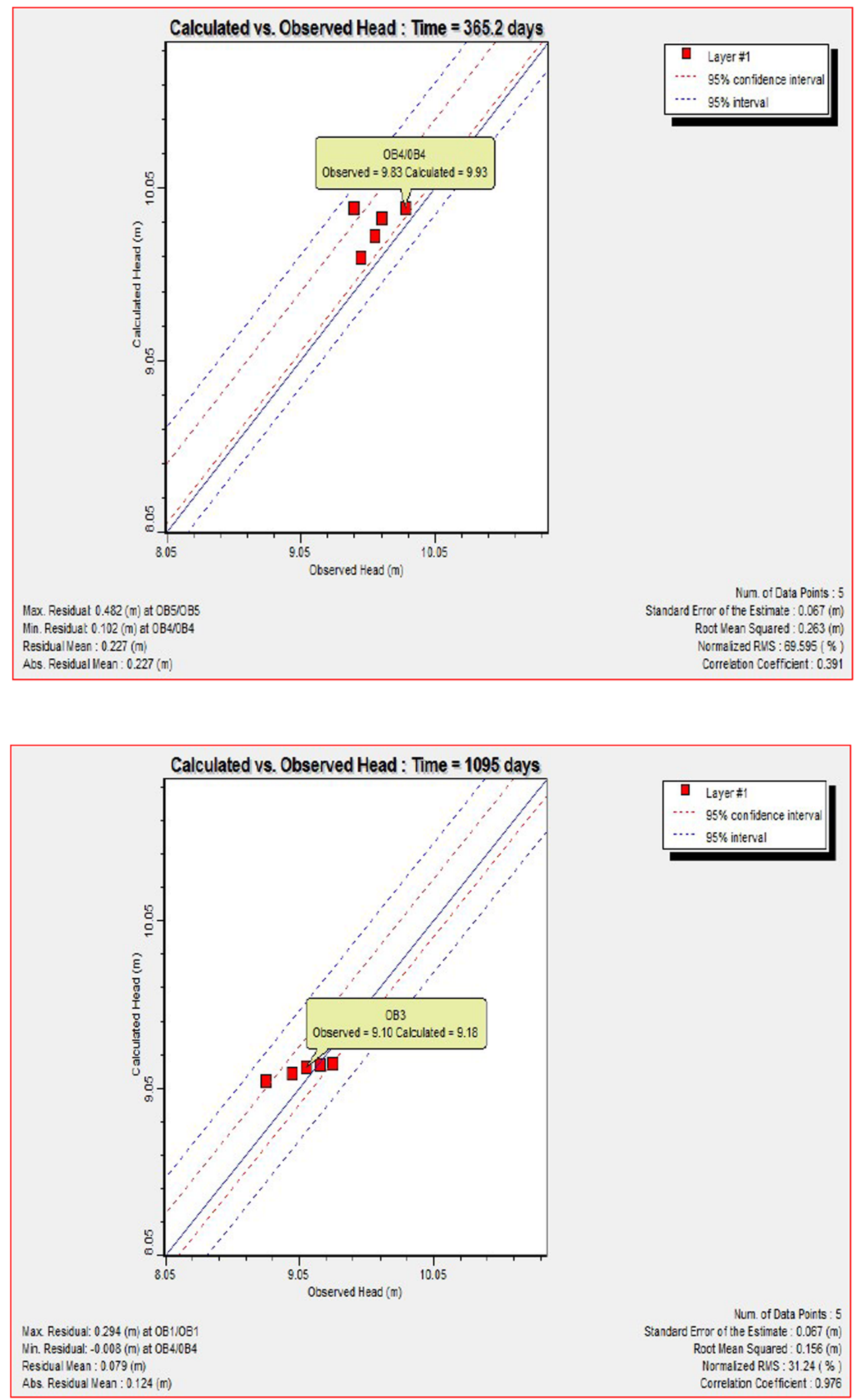

MODFLOW (Guiguer and Franz 1996). Water Hydrogeological Software (WHS) solver package of MODFLOW has been used for groundwater flow computation. This solver checked the maximum change in the solution at every cell after completion of each iteration. If the maximum change in the solution is below the set of convergence 
Table 3 Comparative study of observed vs. calibrated head values at 1095 days

\begin{tabular}{lll}
\hline Well no. & $\begin{array}{l}\text { Observed head } \\
\text { (traditional values) } \\
\text { (input data) }\end{array}$ & $\begin{array}{l}\text { Calculated head } \\
\text { (calibrated values) } \\
\text { (output data) }\end{array}$ \\
\hline OB1 & 8.80 & 9.09 \\
OB2 & 9.00 & 9.14 \\
OB3 & 9.10 & 9.18 \\
OB4 & 9.12 & 9.20 \\
OB5 & 9.20 & 9.30 \\
\hline
\end{tabular}

tolerance (here $0.01 \mathrm{~m}$ ), then the solution has converged and the solver stops, otherwise, new iteration will start (McDonald and Harbaugh 1988). The groundwater flow model has converged after 50 iterations. The purpose of the calibration of a groundwater flow model is to demonstrate that the model can response field measured heads and flows. A trial and error calibration technique has been used. The flow model was calibrated by adjusting several parameters (permeability, recharge, river stage and aquifer thickness) within a narrow range of values until the best fit was obtained between the observed heads and simulated heads (Mayer et al. 2007). The accuracy of the computed groundwater levels was judged by a mean error, mean absolute error and root mean square error of computed values for points on the graph (Anderson 1992) (Figs. 12, 13, 14).

\section{Conclusions}

Groundwater model has become a commonly used tool for hydrogeologists to perform various tasks. The rapid increase of computing power of PCs and availability of user friendly modeling systems has made it possible to simulate large scale regional groundwater systems. The present modeling study is very preliminary and subject to many assumptions and assumed hydraulic parameters. Groundwater models are tools which are frequently used in studying groundwater flow systems. A ground water model is a simplified representation of a more complex reality. They have proven to be useful tools over several decades for addressing a range of ground water problems and supporting the decision-making process. Ground water modeling involves voluminous data; accuracy of result depends on the availability of data on various input parameter. With the available data the simulated hydraulic heads using MODFLOW and observed hydraulic heads were shown better correlation. Variations in the observed and simulated water levels were noticed for the wells that are near the river and it is due to the lack of insufficient river flow data for this area. In the present study, a MODFLOW model is developed to estimate head calibration of a part of Mahesh River basin with the known boundary conditions and field observations. The field monitoring is incorporated to verify model predictions. The best method of reducing modeling errors is to apply good
Fig. 12 Calibration residuals histogram of cal. vs. obs. head (January 2013-2014)

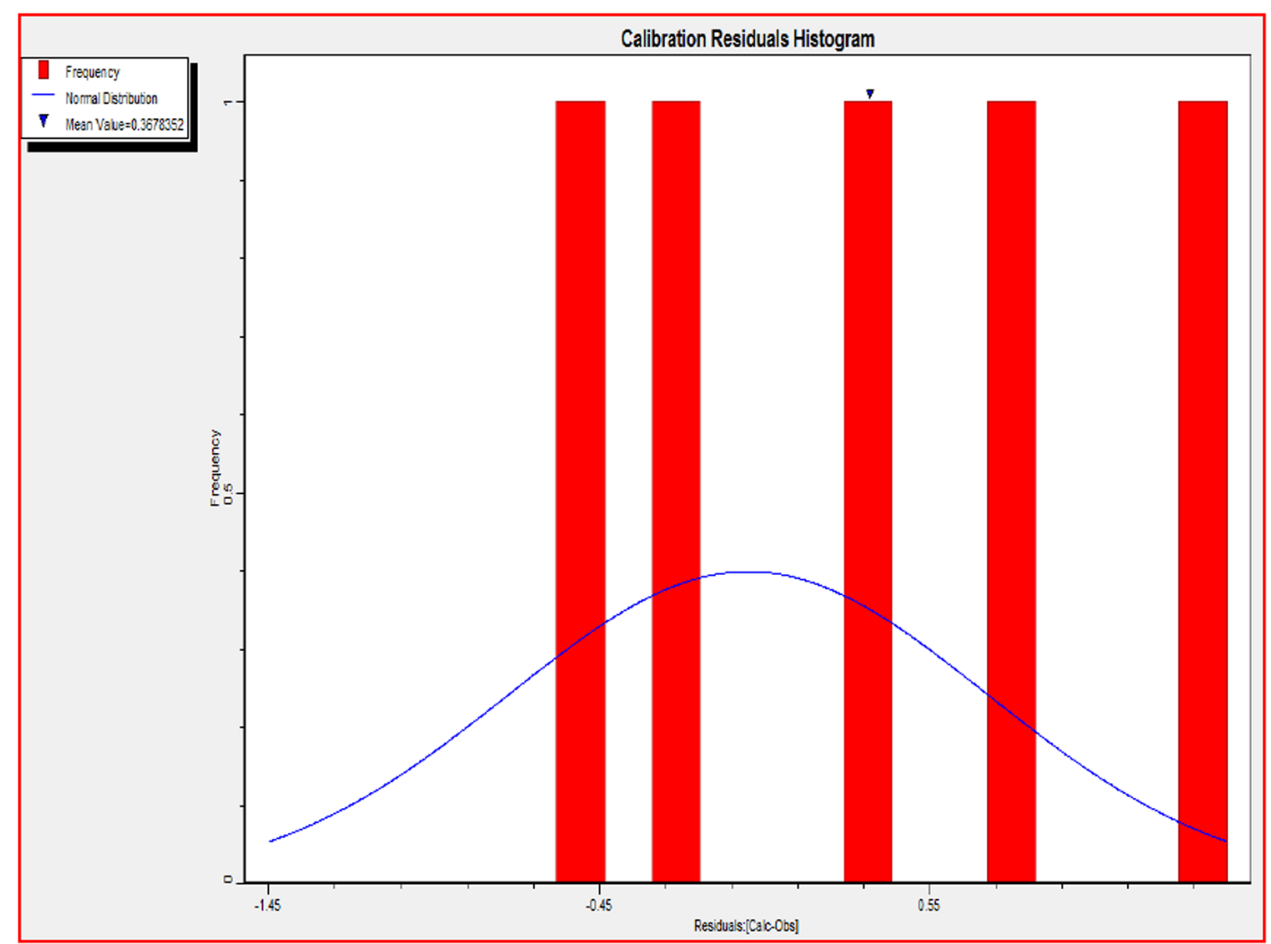


Fig. 13 Computed water level contours in the unconfined aquifer (January 2013)
Fig. 14 Computed water level contours in the unconfined aquifer (January 2014)
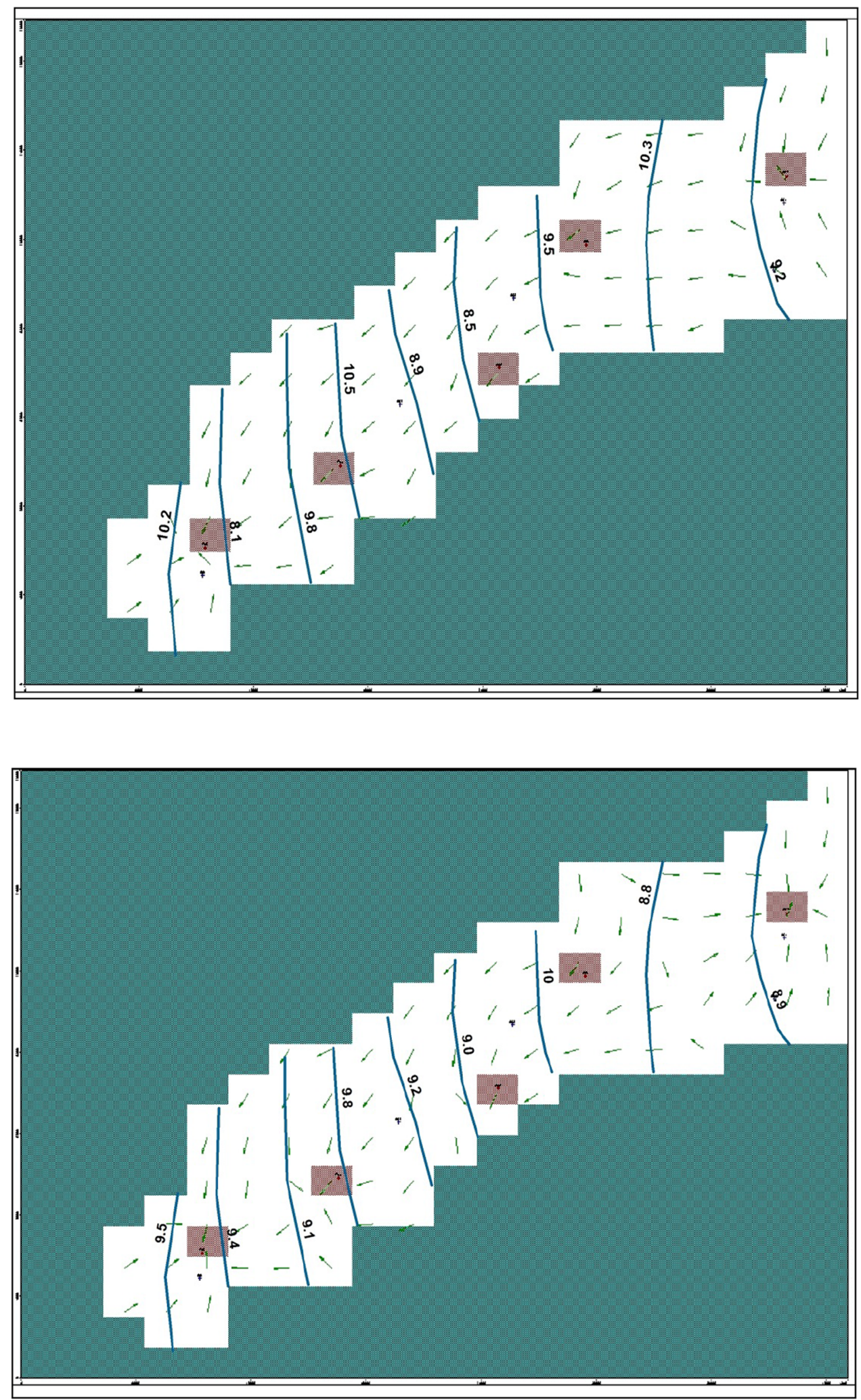

hydrogeological judgment. The model calibration has been performed based on the available data. The model results show that the computed values are in good-fitness of the measure data, which indicate the model is reliable. Similar studies can be undertaken for other water stressed areas for reliable water resources estimation adopted in better and 
efficient water resources planning and management. Continuous measurements of water budget components and groundwater levels will build up databases required for analysis of regional flow systems and construction of regional transient groundwater models. The model should be used to simulate impacts of human activities on groundwater flow systems, to formulate sustainable groundwater resources development scenarios, and to communicate the results to public and decision-makers. The results of calibration showed that the predicted results matched well with the observed data. The model could be used to predict the groundwater levels variation under different hypothesis conditions in Mahesh River basin, which would provide the effective reference to the rational use and management of the groundwater.

\section{References}

Anderson TW (1992) Electrical-analog analysis of the hydrologic system, Tucson basin, Southeastern Arizona. U.S. Geological Survey Water-Supply Paper 1939-C, p 34

Anon (2000) SSG software. The Scientific Software Group, Washington. http://www.scisoftware.com

Boulton NS (1954) Unsteady radial flow to a pumped well allowing for delayed yield from storage. Int Assoc Sci Hydrol Publ 37:472-477

Boulton NS (1963) Analysis of data from non-equilibrium pumping tests allowing for delayed yield from storage. Proc Inst Civ Eng 26:469-482

Boulton NS (1973) The influence of delayed drainage on data from pumping tests in unconfined aquifers. J Hydrol 19:157-169

Bredehoeft JD, Konikow LF (1993) Ground-water models: validate or invalidate. Ground Water 31(2):178-179

CGWB (1997) Groundwater estimation methodology. Central Ground Water Board, Ministry of Water Resources, Govt. of India
Chiang W-H (2005) 3D-groundwater modeling with PMWIN: a simulation system for modeling groundwater flow and transport processes. Springer, Berlin. doi:10.1007/3-540-27592-4

Cooley RL (1977) A method of estimating parameters and assessing reliability for models of steady state ground-water flow, 1 . Theory and numerical properties. Water Resour Res 13(2):318-324

Cooley RL, Case CM (1973) Effect of a water table aquitard on drawdown in an underlying pumped aquifer. Water Resour Res 92:434-447

Datta PS (2002) Groundwater situation in New Delhi: red alert. Nuclear Research Laboratory, IARI, New Delhi

Diersch H-J (2009) FEFLOW Finite Element Subsurface Flow \& Transport Simulation System, Reference Manual. WASY GmbH Institute for Water Resources Planning and System Research, Berlin

Guiguer N, Franz T (1996) The integrated modeling environment for Modflow and Modpath (Visual Modflow). Waterloo Hydrogeologic Software, Waterloo, p 234

Gupta CP, Thangarajan M (1990) Management of groundwater resources in India using simulation models. Water Resour $\mathbf{J}$ March 1990:34-42

Hani A, Djorfi S, Lamouroux C, Lallahem S (2007) Impact of the industrial rejections on water of Annaba aquifer (Algeria). Eur Water 19(20):3-14

Konikow LF, Bredehoeft JD (1992) Ground-water models cannot be validated. Adv Water Resour 15(1):75-83

Mayer A, May W, Lukkarila C, Diehl J (2007) Estimation of faultzone conductance by calibration of a regional groundwater flow model: desert Hot Springs, California. Hydrol J 15(6): 1093-1106

McDonald MG, Harbaugh AW (1988) A modular three-dimensional finite difference groundwater flow model. US Geological Survey Open-file Report 83-875, p 528

Oreskes N, Shrader-Frechette K, Belitz K (1994) Verification, validation, and confirmation of numerical models in the earth sciences. Science 263:641-646

Popper K (1959) The logic of scientific discovery. Harper and Row, New York

Wingle WL, Poeter EP, McKenna SA (1999) UNCERT: geostatistics, uncertainty analysis and contaminant transport modeling. Comput Geosci 25:365-376 